\title{
Angry laughter: Postcolonial representations of dictatorial masculinities
}

Charlotte Baker, Lancaster University

\begin{abstract}
Focusing on the representation of the masculinity of dictator figures in Cheik Aliou Ndao's Mbaam dictateur (1997) and Baba Galleh Jallow's Angry Laughter (2004), this article explores the imbrication of social realities, power structures and literary expression that characterizes these texts as dictator-novels. It considers the writers' reappropriation of the border between animal and human as a means by which to level an allegorical political critique in the guise of a fable. In so doing, it emphasizes their representation of the hypermasculine body of the dictator and its centrality to emerging nation states that are defined by class and ethnic relations. Finally, its focus turns to the importance of voice to examine the aesthetic of these two dictatornovels, which is of equal importance to our understanding of these texts as their thematic representation. The article thus takes these two literary works as case studies for the dictatornovel at the turn of the twenty-first century to examine the ways in which African writers use the dictator-novel to express the disenchantment of citizens with the long and faltering process of decolonization that, in many countries across Africa, had seen the emergence not of an ideal postcolonial democracy, but instead of a de-humanizing neo-colonial autocracy.
\end{abstract}

\section{Résumé}

En mettant l'accent sur la représentation de la masculinité des dictateurs dans Mbaam dictateur de Cheik Aliou Ndao (1997) et Angry Laughter de Baba Galleh Jallow (2004), cet article propose d'examiner l'imbrication des réalités sociales, des structures de pouvoir et de l'expression littéraire qui caractérisent ces textes comme des romans de la dictature. L'article 
considère la réappropriation littéraire des frontières entre animal et humain comme un moyen permettant de porter un jugement critique allégorique politique sous prétexte d'une fable. Dans ce cadre, l'article souligne la représentation du corps hyper-masculine du dictateur et la centralité de ce corps aux états-nation émergents qui sont définis par des rapports de classe et des relations inter-ethniques. Enfin, l'article appuie sur l'importance de la voix pour signaler que les esthétiques de ces deux romans de la dictature sont d'une importance égale à la représentation thématique pour notre compréhension de ces textes. Ainsi, l'article prend ces deux romans comme étude de cas pour le roman de la dictature au début du $21^{\mathrm{e}}$ siècle pour examiner comment les écrivains africains utilisent le roman de la dictature pour exprimer le désenchantement des citoyens avec le long et hésitant processus de la décolonisation qui, dans plusieurs pays africains, a conduit à l'émergence non pas d'une démocratie postcoloniale idéale, mais d'une autocratie néocoloniale déshumanisante.

\section{Keywords}

dictator-novel

masculinities

postcolonial nationalisms

performance of power

Cheik Aliou Ndao

Baba Galleh Jallow

\section{Introduction}

In postcolonial Africa, political masculinities have both a quantitative dimension, with male domination of the highest state positions, and a qualitative dimension, with political power manifested through violence, authoritarianism, and the personalization of power (Mouiche 
2008: 13). Following Kathleen Starck and Birgit Sauer, political masculinity is understood here as masculinity that is 'constructed around, ascribed to, or claimed by those in the political domain' (Starck 2014: 6). Lahoucine Ouzgane and Robert Morrell's landmark 2005 study African Masculinities: Men in Africa from the Late Nineteenth Century to the Present begins from a position that recognizes the diversity of African men, signalling the risk of essentializing and homogenizing rather than acknowledging the diversity and plurality of lived postcolonial masculinities around the globe. At the same time, Ouzgane and Morrell recognize commonalities, acknowledging that all men have access, to varying degrees, to the patriarchal dividend that gives them the power to choose to exercise power over women and other men, but remind us that 'in Africa, men have the legacy of colonialism and the current impact of globalization to contend with, as well as their complex positioning as "other" (2005: 7). Indeed, in Masculinities, Raywen Connell emphasizes that definitions of masculinity are:

deeply enmeshed in the history of institutions and of economic structures. Masculinity is not just an idea in the head, or a personal identity. It is also extended in the world, merged in organized social relations. To understand masculinity historically we must study changes in those social relations. (1995: 29)

Thus, masculinities cannot be detached from the social and political context in which they are embedded, but the study of masculinities necessitates an interrogation of its intersections with other social realities such as class and ethnicity. Dictatorial masculinities in Africa must be read and understood through the various networks of political and social relations that constitute each dictatorship; networks that are shaped by colonialism and globalization. 
This article examines the creative strategies adopted by the Senegalese writer Cheik Aliou Ndao and Gambian writer Baba Galleh Jallow to represent dictatorial masculinities in their fictional works as a means by which to explore the borderland between colonialism and the postcolonial. In so doing, it contributes to scholarship on the literary traditions of Senegal and Gambia, two closely connected West African countries with very different political and historical trajectories. Focusing on the representation of the masculinity of the dictator figures in Ndao's Mbaam dictateur ${ }^{1}$ (Ndao 1997) and Jallow's Angry Laughter (Jallow 2004), it examines how the novels open up associations with humanization and dehumanization as political and aesthetic categories more broadly. It explores the imbrication of social realities, power structures and literary expression that characterizes these texts as dictator-novels. The article then considers the writers' reappropriation of the border between animal and human as a means by which to level an allegorical political critique in the guise of a fable, emphasizing their representation of the hyper masculine body of the dictator and its centrality to an emerging nation state that is defined by class and ethnic relations. Finally, the focus turns to the importance of voice to examine the aesthetic of these two dictator-novels, which is of equal importance to our understanding of these texts as their thematic representation. The article takes these two literary works as case studies for the dictator-novel at the turn of the twentyfirst century; a sub-genre that has been used in post-independence Africa to express disenchantment with the long and faltering process of decolonization that in many countries has seen the emergence not of an ideal postcolonial democracy, but instead of a de-humanizing neo-colonial autocracy. It argues that the turn of the twenty-first century marks a moment of transformation in the African literary history of the dictator-novel, a sub-genre of writerly social critique.

\section{Colonialism, political and social change in West Africa}


In West Africa, the most significant changes in social relations in the twentieth century were brought about by the experiences of colonialism and independence. Independence for both Senegal and the Gambia came in the 1960s. The Gambia achieved independence on 18 February 1965, becoming a constitutional monarchy within the Commonwealth. The national government immediately held a failed referendum proposing that the country become a republic, and it was only with a second referendum in 1970 that The Gambia became a republic within the Commonwealth and Dawda Kairaba Jawara of the People's Progressive Party (PPP) assumed the office of President. While The Gambia is frequently referred to as Africa's oldest multiparty democracy, others recognize that despite the appearance of a vibrant multiparty democracy, The Gambia could be characterized as having a de facto single-party system (Loum 2002: 154). The Presidential system heavily favoured the incumbent president and his party and, while Gambian opposition parties were permitted to compete in elections, it was impossible for them to break the PPP's monopoly on power. As Momodou Loum remarks, ' $[\mathrm{O}] \mathrm{n}$ the surface, the Gambian political and economic set-up seemed like a success story. But in reality, it was hollow and dominated by a small elite that monopolized the system to its own advantage' (2002: 155). President Jawara ruled from 1970 to 1994 until a military coup d'état in 1994 brought an end to his single-party rule, giving birth to the repressive autocracy of Yahya Jammeh, who took power in 1994. Jammeh successfully transformed himself from military ruler to elected civilian president, but his regime has frequently been condemned for its violence, human rights abuses and constraints on the freedom of the press. The transition of power between Jawara and Jammeh is at the heart of Baba Galleh Jallow's novel, as he portrays a leader who has been in power for so long that he has become divorced from the realities of the people he rules over and a coup d'état that will bring about change, but not for the better.

The political turbulence of Senegal at the end of the twentieth century also underpins the action of Ndao's novel, although unlike The Gambia, Senegal has never had a true autocrat 
in power. On 4 April 1959, Senegal and the French Sudan had merged to create the Mali Federation, which became independent from France on 20 June 1960. When the Federation broke up in August due to internal political difficulties, Senegal and French Sudan (renamed the Republic of Mali) each proclaimed independence. Léopold Sédar Senghor was elected Senegal's first president in August 1960, heading up the Parti Socialiste du Sénégal ('Senegalese Socialist Party'). Faced with the various challenges of economic decline, and with hopes of meaningful social change gradually fading, Senghor's drift into single-party rule ensured stability and by 1966 he had established a de facto one-party state (Galvan 2001: 52). At this time, Senegal was recognized as one of the most liberal and open societies in Africa and in 1976, Senghor reopened Senegalese politics to opposition parties, albeit of a predetermined ideological range. ${ }^{2}$ Although Senghor won the elections in 1978, he resigned from office just two years later, becoming the first African head of state to retire voluntarily. This was the first of two fair and transparent transitions of power in the postcolonial era in Senegal.

On 1 January 1981, Senghor's protégé Abou Diouf became president, completing Senghor's term and easily winning the 1983 presidential election. However, by the late 1980 s, the technocrat Diouf no longer enjoyed overwhelming popular support. An increasingly effective opposition, the agricultural and economic crisis of the 1980s and International Monetary Fund (IMF) structural-adjustment measures eroded the leader's popularity. While Diouf could count on rural support for his party and its crucial alliance with the major Sufi leaders, allegations of procedural irregularities, ballot intimidation, imprisonment of the opposition and manipulated vote counts marred his victory in the 1988 presidential election, and Diouf had to declare martial law to quell mass demonstrations protesting the election results (Galvan 2001: 58). However, he clung onto power until 2000, when the long-time opposition leader, Abdoulaye Wade of the Union Progressiste Sénégalaise ('Senegalese 
Progressive Union'), ran for President, succeeding at his fourth attempt. Although Ndao's novel levels a commentary that is not restricted to national allegory in the same way as Jallow's novel, it functions as a warning that such a dictator might come to power in Senegal if certain authoritarian tendencies are allowed to persist.

Highlighting the legacy of colonialism for the burgeoning of authoritarian regimes across Africa in the wake of independence, Achille Mbembe remarks that "postcolonial African regimes have not invented what they know of government from scratch' (2001: 24). Mbembe adopts the term commandement to refer to the relations of power in postcolonial Africa, considering it to be built on three pillars: a regime of exception that has departed from common law, a system of privileges and immunities for the few, and a lack of distinction between ruling and civilizing. As such, for Mbembe, the origins and power of commandement are found in the 'colonial rationality', which has its roots in the violence with which colonialism legitimized its foundations and operations. However, it is overly simplistic to argue that the rise of African dictatorships is an inevitable consequence of colonialism. Accordingly, while Mbembe agrees that the postcolonial state in Africa is an extension of the colonial state, with its attendant violence and processes of control, he recognizes the complex interplay of tribalism, nationalism and authority that undergirds the regimes of African dictators, which are visible in the literary texts examined here. The long-standing patterns of power that emerge as a result of colonialism, but that survive well beyond the limits of colonial administrations, are termed 'coloniality' by Nelson Maldonado-Torres and others, ${ }^{3}$ including African scholars such as Frantz Fanon (1961) and Ngugi wa Thiong'o (1986), who have engaged with this problem of coloniality, although not adopting the term itself. As Walter Mignolo articulates,

Coloniality names the experiences and views of the world and history of those whom Fanon called les damnés de la terre ('the wretched of the earth', those 
who have been, and continue to be, subjected to the standard of modernity). (cited in Grosfoguel 2007: 203)

Maldonado-Torres argues that the dismantling of the very relations of power and conceptions of knowledge that fuel the reproduction of racial, gender and geopolitical hierarchies that came into being or found new and more powerful forms of expression in the colonial world can only be achieved by a process of decoloniality (2011: 117). Reading with a decolonial attitude reveals how, by incorporating and crossing the boundaries of history and fiction, dictatornovels make visible the consequences of the coloniality of power, opening up discursive spaces for reading resistance.

\section{Fictions and realities}

While masculine roles in African societies shifted with the arrival of colonialism and again with independence, so too did the focus of the literary critique of power structures. As Samba Diop comments, '[L]e récit postcolonial est caractérisé par un double rejet: le rejet, il est vrai, de l'hégémonie occidentale mais, aussi, de la bourgeoisie nationale postcoloniale' (2002: 23). Since the late 1960s, dictators have figured abundantly in African post-independence literature, including major works characterized by intense social and political commitment such as Ayi Kwei Armah's The Beautyful Ones Are Not Yet Born (London: Heinemann, 1968), Sony Labou Tansi's La Vie et demie (Paris: Seuil, 1979), Ahmadou Kourouma's En attendant le vote des bêtes sauvages (Paris: Seuil, 1998) and Ngũgĩ wa Thiong'o's Wizard of the Crow (New York: Pantheon, 2006). The first African literary representations of dictatorship to appear in the 1960s and early 1970s documented the trauma of post-independence failures and the rise of dictatorial rule but tended to reproduce the myth of the dictator by portraying the power of this figure uncritically. By comparison, the novels discussed here are selected as examples of texts that 
challenge the autocratic, repressive politics of dictatorial regimes through experimentation and aesthetic creativity (Baker 2014: 306). Ndao's Mbaam dictateur and Jallow's Angry Laughter are dictator-novels - not simply literary representations of dictatorship but, in Roberto González Echevarría's terms, literary responses to dictatorship that raise questions about the nature and ways of contemporary political power, the power that constitutes a literary text, and the function of the figure of the author (1995: 65).

Both Ndao and Jallow opt to avoid realism, although part of their intent is to achieve a documentary realism that borrows from reality - that of a specific period in the history of West Africa. Both novels are direct and simple narratives written in the Orwellian tradition. Their meanings lie mainly on the surface, revealing the dystopian nature of dictatorship in which there is no logic or moral justification for the excessive exercise of power. However, that is not to say that formal experimentation is not a characteristic of these texts, as we will see when we come to the question of narrative voice. The writers reflect in their novels a shared sense of disillusionment with regards to decolonization in Francophone and anglophone West Africa, and specifically that political independence did not bring the independence of thought that would bring decolonial freedom. A close reading of the literary structures of Ndao and Jallow's novels and their effects reveals that a focus on masculinities is intrinsic to the writers' critique of the political power that characterizes a dictatorial regime.

In Ndao's novel, the eponymous dictator Wor has come to power in a violent coup d'état. The novel offers a commentary on a period in the transformation of the Senegalese state in the wake of the neo-liberal restructuring that culminated in the economic and social crisis of the 1980s and 1990s. However, it also levels a wider critical commentary on the emergence of dictators across postcolonial Africa in this period. Ndao's protagonist Wor is the epitome of a political masculinity defined by violence and a charismatic heterosexuality: 
Mbaam ngonk, l'âne énorme, a été un grand chef. Il s'est même trouvé à la tête d'un pays où sa volonté se confond avec la loi. Quand il s'y trouve personne ne bouge. Nul ne pense y tousser sans sa permission. Il s'est pris pour le maître de l’Univers, persuadé que tout vient de lui. (1997: 152)

The dictator's performance of masculinity plays a central part in the production of political legitimacy in this fictional nation. When Wor looks out over the crowds of people who have come to listen to him speak, he does not recognize them as individuals, but describes them as 'the masses' who, in his eyes, are responsible for having allowed him to rise to power. The pointed reference highlights Wor's oppression of class, gender and ethnic differences and his assertion of power and control over the people. They have not come to listen to Wor because they want to be there, but because not to come indicates that they oppose the dictator. As the narrator tells us: 'Quand tous les matins on se réveille dans un pays sous le joug d'un dictateur, il ne faut jurer de rien' (1997: 200). Wor maintains himself in power by violently repressing any opposition, ridding the government of any possible opponents and setting up a secret service. On a whim, he changes the constitution and adopts a series of new laws: 'Etant le seul à décider, il change ce qu'il veut. Un dictateur n'a pas de limites. Seul son désir le guide. Il ne consulte personne. Il ne demande pas d'avis. Il n'en fait qu'à sa volonté' (1997: 165). Wor's regime is characterized by fear, intimidation, violence and bloodshed - all designed to reinforce his position and ensure his longevity.

Whereas Wor's regime is defined by brutality, the ruler Talkmuch Dolittle portrayed in Jallow's Angry Laughter has been in power for so long that he has become increasingly divorced from the realities of the people he rules over. Unlike Ndao, Jallow portrays recognizable figures within the political geography of the Gambia as animals in his biting critique of the nation's political landscape over a period of more than thirty years, with the 
humorously named Talkmuch Dolittle as President Dawda Kairaba Jawara and Loony the Fox as Yahya Jammeh. It is clear that the dehumanizing force in this novel is that of dictatorship, but the legacy of colonialism is keenly felt. The nation is divided. On the one side are Loony the Fox and the other security foxes, Skimpy the giraffe, who takes great pride in his height and ability to enjoy the fruits of life at the top, Chokie the bush fowl, the Mental Surveillance moles, and the deeply corrupt Jumbo the Peacock. On the other side are Loony's rivals Cockerel Sir Messiah, Saa the snake who is a notorious liar, Spotty the tiger, Blackie the panther, and the unnamed masses - the animals of Smiling Forest.

George Orwell comments in his 1946 essay 'Why I write' on how he brought together his gifts as a novelist and his commitment as a political writer. He remarks that 'Animal Farm was the first book in which I tried, with full consciousness of what I was doing, to fuse political purpose and artistic purpose into one whole' (Orwell and Angus 1970). Ndao and Jallow adopt a similar approach as they play with the border between human and animal in their novels. In recent years, animal studies have attracted increasing attention in postcolonial studies. As Graham Huggan remarks, citing Kari Weil, it is easy to see why the animal turn might attract postcolonial critics:

[It] stretches to the limit questions of language, of epistemology and of ethics that have [long since] been raised in [...] postcolonial studies: how to understand and give voice to others or to experiences that seem impervious to our understanding; how to attend to difference without appropriating it or distorting it; how to hear and acknowledge what it may not be possible to say. $(2015: 2)$

Reading with this border between animal and human in mind and a sensitivity to the questions Weil signals above elucidates Ndao and Jallow's strategy, which lies in their pointed recalling 
of the western reduction of the African to the 'wild' or 'savage' while at the same time reappropriating the border between animal and human. Certainly, their representation of humans in animal form, or theriomorphism, permits Ndao and Jallow to level an allegorical political critique in the guise of a fable. Their narrative choices permit them to make a veiled political commentary through what Robert McKay presents as one of three types of anthropomorphism; the attributing of supposedly human qualities to non-human animals, such as reason, self-awareness, intentionality, purpose and imagination (2018). However, theirs is not just an African engagement with Orwell, but rather an alternative to Orwell that illustrates the value of imaginative literature as a political tool. Through distinctly literary techniques, Ndao and Jallow reappropriate the African tradition of moral tales told by animals explaining how the world has come to be as it is, to satirize the performance of power in the postcolony and to imagine how things might change.

Ndao's Mbaam dictateur and Jallow's Angry Laughter reveal that while those living under dictatorship suffer, those in power devote their energies to reinforcing their own positions. Patronage characterizes African dictatorship, and rulers are surrounded by male associates, clients, supporters and rivals, who constitute what Robert Jackson and Carl Rosberg term 'the system' (1982: 19) and which for Connell represent 'complicit masculinities' (1995: 41). This system is typically kept as small as possible to ensure control and distribution of wealth to individuals of critical importance to the dictator's survival. Jallow's Talkmuch Dolittle is surrounded by

A thick wall of sycophants [that] surrounded and shielded him from the realities on the ground and fed him with multi-coloured layers of convenient truths about the state of the common animals. Everything, they told him, was fine and dandy 
and that in fact, all the animals were ecstatic about the qualities of his great leadership. (2004: 11)

The reality on the ground is rather different though. As living standards fall, government corruption and redundancy rocket, and 'a thick cloud of resentment shrouded the bright landscape of Smiling Forest' (2004: 11-12). The narrative cleverly presents the hypocrisy and self-deception that characterize Talkmuch Dolittle's dictatorship and the parasitic ruling class, but also underscores the resentment of the people, who aspire to a better standard of living. Jallow points to the preference of African dictators to disproportionately favour their own ethnic group, keeping others from the political process. For many years, Loony the Fox has faithfully served Talkmuch Dolittle, rising quickly through the ranks to become commander of the Red Hat Branch that is responsible for his personal security. The end of Talkmuch Dolittle's regime comes with a coup led by Loony the Fox. Despite promising that 'he and his fellow patriotic armed foxes were not there to stay, that they were foxes with a difference and that they were all for truth, equality and justice, transparency, accountability and probity' (2004: 29-30), Loony becomes power hungry and paranoid, proclaims himself a lifelong ruler of Smiling Forest and reinforces his power, 'exacting vengeance on all who spoke out with reckless abandon' (2004: 50). The abuse of power continues, by the same ethnic group, albeit under a different leader.

\section{The hyper masculine body of the dictator}

The body presents a crucial site at which power is explored in these novels and in African dictator-novels more generally. However, in contrast to the construction of hegemonic masculinity formed out of a border - as is the case, for example, of the conquistador or the explorer - here the national body is framed by the centre, and the hegemonic masculinity of 
that centre is the dictator. At a time of nation-building in the wake of independence from the former colonizer, as national space is consolidated, fixity at the centre of that space becomes crucial. However, rather than insisting on the fixity and centrality of the body of the dictator to the emerging nation state, Ndao and Jallow's novels emphasize the fluidity of borders and bodies and raise questions of mobility. Here, aesthetic structure and political purpose merge in an Orwellian expression of refusal to position the dictator at the centre and to fix him in power.

In Jallow's Angry Laughter, the transformation of Loony the Fox into a dictator is primarily a physical transformation and that transformation comes to signify the instability of the nation. His is a hyper masculinity that is characterized by his physical size, an exaggerated sexuality and aggressive control over others. Loony describes his intolerance of 'any puny little fellows' (2004: 48) telling him what to do, and it is striking that 'as Loony grew fatter, the animals grew thinner' (2004: 50). Loony's performance of gender is central to the development of his image and is portrayed as being crucial in both his rise to power and his manner of exercising it. Most noticeably, Loony starts to dress differently, taking to 'wearing zebra skins and a zebra hood and carrying a cow horn in one hand and monkey tail in the other' (2004: 48). As Benjamin Ngong acknowledges, the rules of clothing play a significant part in the formation of African postcolonial sovereignty, becoming an instrument of manipulation through which power is legitimized and the social body controlled (2012: 90). We find an allusion to the model for Loony's representation in Jallow's remarks of Yahya Jammeh in his academic article 'Leadership in postcolonial Africa':

In 2014 Gambia, Yahya Jammeh, a former poor and scrawny lieutenant who seized power in the 1994 military coup, is now a hefty millionaire with fat, shining cheeks, who dresses like a medieval sultan, complete with a sword and worry beads in one hand, and a 'holy' book in the other. He claims to be possessed of spiritual and 
supernatural powers and the capacity to cure HIV/AIDS, impotence, asthma, infertility, and cancer among other ailments using traditional African means. With only a high school education he insists on being called His Excellency the President, Sheikh Alhaji Professor Dr Yahya A. J. J. Jammeh Nasiru Deen Babili Mansa. (Jallow 2014b: 12-13)

Here Jallow reiterates one of the greatest critiques levelled at Jammeh: his lack of formal education and openness to witchcraft-related beliefs and superstition that make him ill-suited to lead the nation.

Jallow's comment on Jammeh's rise from 'a poor and scrawny lieutenant' to 'a hefty millionaire with fat, shining cheeks, who dresses like a medieval sultan' eloquently speaks to dictatorial masculinities as forms of reiterated performance. In Ndao's Mbaam Dictateur too, the dictator's clothing contributes to the image he projects as, dressed in his military uniform and sunglasses, he looks out at the people: 'Le dictateur, lui, ne bouge ni ne parle. Il se tient dans son uniforme de maréchal. Des lunettes de soleil cachent ses yeux. Il ressemble à une statue de pierre' (1997: 178). While Wor's clothing is a means by which the dictator performs his power, his party members and supporters are required to wear clothes made from printed African cloth on which his image is reproduced to represent their loyalty to the regime in a visual medium of political expression. This control over the bodies of others recalls Michel Foucault's identification of the body as central to the systems of organization and 'discipline' of modern societies. For Foucault, bodies are not merely natural, biological entities, but serve as the target and support of multiple relations of political power, fashioning docile and productive citizens from otherwise impulsive and unruly individuals (1977: 136). The bodies of the populace become the target of the regime's violence too, as individuals are arrested, imprisoned, raped, tortured and killed. While for the dictator and his sycophants the body 
projects the leader's masculinity and power, the bodies of his followers are emasculated, something to control, to exercise authority over and to disempower. Here we find a literal biopolitics at work, which Foucault describes in The Will to Knowledge as '[A] power that exerts a positive influence on life, that endeavours to administer, optimize, and multiply it, subjecting it to precise controls and comprehensive regulations' (1976: 137). A false hierarchy is imposed and exercised where none should exist. If we recall McKay's discussion of the false border between the animal and the human, and his assertion that all hierarchies are ideological and 'no species is straightforwardly better than any other' (2018: n.pag.), we are in turn forced to consider the validity of a power invested in a body that is given meaning in this way.

It is therefore significant that the transformation of the dictator into a donkey in Mbaam Dictateur is primarily a physical one. The title Mbaam Dictateur blends the Wolof for 'donkey' with the French for 'dictator' to refer to Wor's transformation by an occult practitioner. The choice of animal is carefully considered by those who wish to rid themselves of the dictator, compared to the alternatives of a pig, which is considered too well fed and does not work, and a horse, which works hard but might be spoilt by an over-indulgent master. The donkey is finally chosen because of his thankless hard work: 'C'est lui le compagnon de l'homme. C'est lui qui l'aide. Et pourtant jamais remercié! Aucune commisération à son égard. On ne lui attribue que les travaux les plus pénibles' (Ndao 1997: 235) The class implications associated with the choice of a donkey are clear. He is hard working and poorly rewarded for his efforts, positioned as subordinate to the pig, who represents the greed and laziness of the ruling class, and the horse, who represents those who work hard, but are indulged by the ruler to ensure their loyalty. Although transformed into a donkey, Wor's physicality remains central to his identity as Mbaam ngonk, l'âne énorme. As Connell reminds us, the body is a crucial factor in the formulation of masculinity: 'Masculine gender is (among other things) a certain feel to the skin, certain muscular shapes and tensions, certain postures and ways of moving, certain 
possibilities in sex' (1995: 53). Even as a donkey, we are reminded repeatedly of Wor's size, his great strength and his sense of superiority: 'Mbaam ngonk, l'âne énorme, tout en faisant partie du troupeau, ne semble pas se considérer comme l'égal des autres' (Ndao 1997: 44).

Gradually the boundary between Wor's body and the nation becomes blurred, as the despotic body of the dictator looms large over politics, culture and everyday life. His aggressive masculinity is presented as a response to the emasculatory effects of colonization and an assertion of power in the postcolony. Wor's transformation into a donkey marks a turning point in the novel:

Il sautille jusqu'à la glace. L'image qu'elle lui renvoie l'oblige à pousser un cri. Mais il entend plutôt un braiment. Il est en face d'énormes oreilles sur sa tête, des ongles démesurés, la queue, le trait noir partant de l'encolure parcourant l'épine dorsale jusqu'au bas. Ah mon Dieu! On m'a devancé. Que je fasse tout pour sortir du pays. Qu'aucun regard ne se pose sur moi. Pourtant il ne pense pas qu'il a été Wor le dictateur. Ce n'est pas clair en lui. Il ne voit qu'un âne énorme. (Ndao 1997:

In a democracy, the beast of burden carries the burdens of the nation, but here, it is the nation that bears the burden of dictatorial cruelty and repression. The demos is the donkey. The dehumanization of the dictator then, signals the humanization of the nation and Wor's transformed body represents the end of dictatorship.

\section{Competing voices}

While the physicality of the dictator is central to both novels, the question of narrative voice is also foregrounded because of its significance to the performance of power. As Echevarría 
reminds us, 'the dictator, the one who dictates, can be reproduced, and it is that reproduction that rules' (1995: 76). That reproduction functions on many levels in the two novels selected for close reading here, but which have broader significance for our understanding of the function of literature in relation to coloniality. In their representation of dictators in animalform, Jallow and Ndao offer us an unorthodox perspective on dictatorship, but also open up a creative space in which power can be re-imagined and resisted. Their emphasis on challenging the discourse of those in power is pointedly emphasized by the weight they give to the importance of discourse and its manipulation by the dictator. In Jallow's Angry Laughter the ability to dictate is the key to Loony the Fox's successful coup:

Towards late afternoon the voice of a fox came on the air. [...] The government of Talkmuch Doolittle he declared, was no more. The patriotic armed foxes had decided to rid Smiling Forest of the corrupt monarch and his decadent cohorts. [...] This was the era of reality and hard work! Down with Talkmuch Doolittle! Down with corruption! Long live the glorious armed foxes of Smiling Forest! (2004: 26)

The circulation of newspapers and the widespread use of radio sets allow the dictator to address, summon, and direct the actions of the people. The official press becomes more than simply a vehicle of propaganda, acting instead as a mouthpiece by which the dictator can reach the public. While the voice of the dictator reaches every corner of the nation, Loony's rule is characterized by the repression of any opposition. Journalists in particular are perceived as a threat in a nation in which 'truth becomes lies and lies truth' (2004: 24), and are disappeared, 'relegated to the status of unwanted pariahs - jailed, beaten up, shot dead, sent scrambling for dear life into distant hostile lands where they are considered third class citizens and have to endure all manner of shameful and degrading treatment' (2004: 24). Likewise, Ndao's dictator 
Wor refuses to acknowledge any other voice while in power. He aspires to hear only his own voice or echoes of it, giving speeches and broadcasting his words on the radio: 'Wor ne peut rester une semaine sans qu'on l'entende. S'il ne se sert pas de la radio, il profite d'un grand rassemblement. Ou bien escorté de ses courtisans, il fait le tour des bureaux, des ateliers, des chantiers' (1997: 180).

It is striking then that Ndao's donkey is mute and the transformed Wor has no voice. These dictators, who relied on the ability to dictate, can now only listen. Ndao's novel cleverly reflects this tension back onto its own narration. The narrative of Mbaam Dictateur is polyphonic - an accumulation of voices and speech. ${ }^{4}$ The thread of the story is repeatedly dropped and then picked up again by the various speakers and narrators. By highlighting the unreliability of voice, Ndao undermines the reliance of the dictator on rhetoric as a means by which to reinforce his status and shape the world to his own ends. However, as Tobias Warner remarks, there seems to be an anxiety in Ndao's novel that the work of the novelistic narrator is ultimately on a par with that of the dictator; that both are struggling for absolute mastery and monovocality within a certain domain populated by many other competing voices (2012: 86). Here, he remarks, the border between the writer's world and that of the character is breached, and we start to hear the voice of Wor the dictator begin to interrupt the narrator's account to comment on a particular scene, or even quarrelling with his own portrayal:

N'aie pas peur. C'est moi qui te parle. Tu tentes de raconter mon histoire. Tu veux la confier au papier afin qu'elle trouve refuge dans les mémoires. Je te parle. Depuis que tu as commencé je te suis, je t'observe. (Ndao 1997: 205)

This breaching of the border between narrator and speaker draws the reader's attention to the fictional quality of the narrative and serves as a reminder of what Echevarría describes as 'the 
power, the energy that constitutes a literary text, particularly a novel, and the function within it of the author' (1995: 65). It underscores the instability of the dictator-novel as neither a realistic representation nor a purely fictional artefact, but occupying ground somewhere between the two. At the same time, it points to the ambiguous status of the writer who, in the postcolonial African context, is both a writer of fiction and a political commentator, both external to and implicated in the narrative.

Whereas Jallow's Angry Laughter is dominated by the voice of the omniscient narrator who recounts Loony the Fox's life under Talkmuch Dolittle and his rise to power, in Mbaam Dictateur, the dictator's struggle to monopolize discourse becomes a fictive double of Ndao's narrator, and even at times a rival one (Warner 2012: 86). The narrator in Mbaam Dictateur makes this tension explicit as he describes the story he is telling as 'a fabric of inventions':

Seule la fiction permet d'accepter ce que la logique rejette. L'esprit ne reçoit que ce qui est prouvé, évident, certain, palpable. L'on se soumet à la fiction à cause de ce qu'elle vise dès le départ. Aussi en l'écoutant ne sépare-t-on rien. L'animal, le végétal, l'homme se mêlent, parlent, marchent, pensent, font preuve des mêmes capacités. Pas une seule différence entre eux. (Ndao 1997: 265-66)

By so insistently highlighting the permeability of borders, Ndao suggests that fiction is the ideal vehicle by which to expose and break them down. The degradation that Ndao points to here recalls Bakhtin's notion of carnivalization as a literary mode that at once subverts and liberates (1984).

The narrative power to not distinguish between subjects and objects, to make everything intermingle, is also a defining feature of Wor the dictator's rule. The nation is described as 'un jouet entre les mains du dictateur' (Ndao 1997: 173) and he dominates every aspect of life 
there. The representation of Wor demonstrates that, just as borders can be manipulated into a political discourse to reinforce a particular form of hegemonic masculinity, fiction can expose all borders as artificial and therefore subject to legitimate scrutiny. In striking contrast to the controlled and controlling space of the nation under Wor's dictatorship, Ndao's novel is a space in which discourse accumulates, and characters takeover the role of the novelist. As Warner explains, the novelist becomes just like the mute donkey, in a privileged position from which to overhear the entire goings on, but unable to participate: 'The donkey in the family concession functions as the Wolof equivalent of the fly on the wall: a being that no one notices and before whom one can say anything' (2012: 86). As such, both the donkey and the dictator double the 'work' of the fictional, novelistic speaker: one appears to be in command of the fictional universe, while the other is merely an eavesdropper whose work is ultimately not his own (Warner 2012: 86). Thus, Ndao's novel explicitly focuses attention back on the writer and his role in the face of dictatorship. He calls on writers to reconfigure borders imaginatively in the face of the unimaginative borders of political control, even going so far as to level a direct criticism at intellectuals who fail to stand up to authoritarian regimes.

While Jallow's novel exposes the fear and violence that characterize Loony's regime and prevent people from speaking out, the narrator of Ndao's Mbaam Dictateur turns his criticism on intellectuals, reminding readers that: 'Par la suite, la mauvaise foi et l'intérêt ont amené les gens à se comporter en admirateurs devant les dictatures. Il n'y a rien de pire qu'une époque trahie par ses intellectuels' (1997: 261). As the voice of the voiceless in society, the African writer has been pitted against the colonial masters and against postcolonial dictators, often with grave consequences. Many African writers and intellectuals have been killed, incarcerated, forced into exile or their works banned or censored under dictatorial rule. As Niyi Osundare remarks: 
The freedom to stand and stare is basic to any creative leap. Unfortunately, that is a state of existence that is in peril virtually everywhere in Africa today. And so, the conscientious writer has to keep looking over his/her shoulders, waiting for the next knock on the door, considering with mortal awe the kind of adjective that should go with her/his noun. (2002: 8)

While committed African writers have never shied away from a critique of their leaders, the focus on the role of the writer in these dictator-novels written at the turn of the twenty-first century is a reminder that the very act of writing implicates them in a struggle over discourse with the dictator. They must continue to speak out in the face of the lies, exploitation and dehumanization of dictatorial leaders.

\section{Conclusion}

Taken as examples of dictator-novels published at the turn of the twenty-first century, Ndao's Mbaam dictateur and Jallow's Angry Laughter reveal the complex interrelation of power and gender in the African postcolony in which masculinities and nationalisms are inextricably linked. In their representation of their dictator protagonists, the narratives provide an insight into the psychology of the dictatorial leader and his control over a nation. However, both Ndao and Jallow adopt a variety of literary strategies by which to reveal their protagonists' performance of power and to examine where the responsibility for dictatorship lies in the African postcolony. They operate what Jallow defines in an academic article on the subversive potential of cartoons depicting Kwame Nkrumah's rule in Ghana as a form of 'angry laughter':

Regular cartoons often reflect dissenting opinion, a degree of public anger or a spirit of activism against any number of perceived social ills. They are a form of 
'angry laughter' indulged at the expense of the perceived perpetrators of 'social ills'. They are often on the side of the underdog and potentially subversive of authority, secular, religious or otherwise. (2014: 79)

While on the surface ridiculous, even grotesque, the transformation of the dictator-protagonists in Ndao and Jallow's novels is a powerful means by which to satirize the performance of power in the postcolony. Mbaam dictateur and Angry Laughter portray patriarchal authoritarian dictators who are constructed as fictionalized emblems of the very same cultural logic that characterized colonial rule. By focusing on the representation of the political masculinity and related questions of class and ethnicity in these novels, we are better able to understand the imbrication of dictator-novels that are deeply critical of postcolonial politics in the inherently colonial structures of politics and culture. Their representation of African political masculinity at the borderland between colonialism and the postcolonial reveals the writers' disillusionment with regards to decolonization in West Africa, and specifically their frustration that political independence did not bring independence of thought that would bring decolonial freedom.

\section{Acknowledgements}

This article was developed from a paper presented at the Border Masculinities Symposium at Lancaster University in 2014, organized by Chris Harris, Amit Thakkar and Brian Baker. I am grateful to them and to other colleagues who provided valuable intellectual input throughout the preparation of this article.

\section{References}

Baker, Charlotte (2014), 'Necropolitical violence and post-independence Guinean literature', International Journal of Francophone Studies, 17:2, pp. 305-27. 
(2018), 'Introduction: Performances of sovereignty in African dictator-fiction', Research in African Literatures, 49:3, pp. vii-xii.

Bakhtin, Mikhail (1981), The Dialogic Imagination: Four Essays, Austin: University of Texas Press

(1984), Rabelais and His World, Bloomington: Indiana University Press.

Connell, Raewyn (1995), Masculinities, Cambridge: Polity Press.

Coplan, David (2010), 'Introduction: From empiricism to theory in African border studies', Journal of Borderlands Studies, 25:2, pp. 1-5.

Diop, Samba (2002), Fictions africaines et postcolonialisme, Paris: Harmattan.

Echevarría, Roberto González (1995), The Voice of the Masters: Writing and Authority in Modern Latin American Literature, Austin: University of Texas Press.

Fanon, Frantz (1961), Les Damnés de la terre, Paris: Maspero.

Foucault, Michel (1976), The Will to Knowledge: The History of Sexuality, vol. 1, London: Vintage.

(1977), Discipline and Punish, London: Vintage. 
Galvan, Dennis (2001), 'Political turnover and social change in Senegal', Journal of Democracy, 12:3, pp. 51-62.

Grosfoguel, Ramón (2007), 'The epistemic decolonial turn: Beyond political-economy paradigms', Cultural Studies, 21:2\&3, pp. 203-46.

Herzberger-Fofana, Pierrette (1999), 'A l'écoute de Cheik Aliou Ndao, écrivain sénégalais', Mots Pluriels, December 1999. http://motspluriels.arts.uwa.edu.au/MP1299ndao.html. Accessed 9 October 2019.

Huggan, Graham (2015), Postcolonial Ecocriticism: Literature, Animals, Environment, London: Routledge.

Jackson, Robert and Rosberg, Carl (1982), Personal Rule in Black Africa: Prince, Autocrat, Prophet, Tyrant, Berkeley: California University Press.

Jallow, Baba Galleh (2004), Angry Laughter: A Biting Satire on an Inept African Civilian Government and Its Brutal Military Successor, Louisville, Wasteland Press.

(2014a), 'From saint to devil: The visual transformations of Kwame Nkrumah in Accra evening news cartoons, 1961-1966', Stichproben. Wiener Zeitschrift für kritische Afrikastudien, 27:13, pp. 79-103. 
(ed.) (2014b), Leadership in Postcolonial Africa: Trends Transformed by Independence,

New York: Palgrave Macmillan.

Loum, Momodou (2002), 'Bad governance and democratic failure: A look at Gambia's 1994 coup', Civil Wars, 5:1, pp. 145-74.

Ly, Abdul (2010), 'Wading in autocracy: Senegal's near-despotism', Harvard International Review, 32:2, pp. 6-10.

Maldonado-Torres, Nelson (2011), 'Thinking through the decolonial turn: Post-continental interventions in theory, philosophy and critique - An introduction', Transmodernity: Journal of Peripheral Cultural Production of the Luso-Hispanic World, 1:2, pp. 1-15.

Mazrui, Ali (1975), 'The resurrection of the warrior tradition in African political culture', Journal of Modern African Studies, 13:1, pp. 67-84.

Mbembe, Achille (2001), On the Postcolony, Berkeley: California University Press.

Mbow, Penda (2008), 'Senegal: The return of personalism', Journal of Democracy, 19:1, pp. $156-69$.

McKay, Robert (2018), 'Approaching Animals in Literature', University of Sheffield, www.sheffield.ac.uk/polopoly_fs/1.473626!/file/BobMcKay.pptx. Accessed 9 October 2019. 
Meredith, Martin (2011), The State of Africa: A History of the Continent Since Independence, London: Simon \& Schuster.

Mignolo, Walter (2000), Local Histories/Global Designs: Essays on the Coloniality of Power, Subaltern Knowledges and Border Thinking, Princeton: Princeton University Press.

(2011), 'Geopolitics of sensing and knowing: On (de)coloniality, border thinking and epistemic disobedience', Postcolonial Studies, 14:3, pp. 273-83.

Mouiche, Ibrahim (2008), 'L'état moderne africain et le patriarcat public', in E. Uchendu (ed.), Masculinities in Contemporary Africa, Oxford: Africa Books Collective, pp. 133-56.

Ndao, Cheik Aliou (1997), Mbaam Dictateur, Paris, Présence Africaine.

Newell, Stephanie (2009), 'Introduction: Postcolonial masculinities and the politics of visibility', Journal of Postcolonial Writing, 45:3, pp. 243-50.

Ngong, Benjamin (2012), 'Costume et pouvoir: la fonction comminatoire du vêtement dans la politique post-coloniale en Afrique', in A. Mazuet (ed.), Imaginary Spaces of Power in SubSaharan Literatures and Films, Newcastle: Cambridge Scholars Publishing, pp. 88-17.

Ngugi, wa Thiong'o (1986), Decolonizing the Mind: The Politics of Language in African Literature, Nairobi: Heinemann. 
Orwell, Sonia and Angus, Ian (1970), The Collected Essays, Journalism and Letters of George Orwell, Harmondsworth: Penguin.

Osundare, Niyi (2002), Thread in the Loom: Essays on African Literature and Cultures, Trenton: African World Press.

Ouzgane, Lahoucine and Morrell, Robert (eds) (2005), African Masculinities: Men in Africa from the Late Nineteenth Century to the Present, London: Palgrave Macmillan.

Perfect, David (2008), 'Politics and society in The Gambia since independence', History Compass, 6:2, pp. 426-38.

Quijiano, Anibal (2000), 'Coloniality of power and social classification', Journal of World Systems, 6:2, pp. 342-86

Rai, Alok (1988), Orwell and the Politics of Despair: A Critical Study of the Writings of George Orwell, Cambridge: Cambridge University Press.

Starck, Kathleen (2014), A Man's World? Political Masculinities in Literature and Cultures, Newcastle: Cambridge Scholars Publishing.

Uchendu, Egodi (ed.) (2008), Masculinities in Contemporary Africa, Oxford, Africa Books Collective. 
Warner, Tobias Dodge (2012), 'The limits of the literary: Senegalese writers between French, Wolof and world literature' Ph.D. thesis, Berkeley: University of California.

Yewah, Emmanuel (1990), 'Political rhetoric in/and the African text', Research in African Literatures, 21:2, pp. 67-78.

\section{Contributor details}

Charlotte Baker is senior lecturer in French and Francophone studies in the Department of Languages and Cultures at Lancaster University. Her research focuses on contemporary African literature written in French and English and she is interested in questions of power and marginality, disability and the body. Her work on African dictator fiction includes her article 'Necropolitical violence and post-independence Guinean literature' in the International Journal of Francophone Studies (2014), her introduction to a special issue of Research in African Literatures on performances of sovereignty in African dictator-fiction, which she edited in 2018 and her article for the special issue, 'Burkinabè Dictator-Novels and the Struggle against Impunity'. Most recently, she co-edited with Hannah Grayson the volume Fictions of African Dictatorship: Cultural Representations of Postcolonial Power (Peter Lang, 2018).

Contact:

Department of Languages and Cultures, Lancaster University, County Main B171, Lancaster LA1 4YT, UK.

E-mail: c.baker@lancaster.ac.uk

ORCID: https://orcid.org/0000-0002-8946-7162 
Notes

\footnotetext{
${ }^{1}$ Aliou Ndao originally wrote Mbaam Aakimuu in Wolof, publishing the novel in French as Mbaam Dictateur in 1997 and, several years later, published it in Wolof with Éditions OSAD in Dakar in 2007.

${ }^{2}$ His renamed Socialist Party (PS) stood as the official socialist choice. The Senegalese Democratic Party (PDS) was designated to represent a liberal, right-of-centre alternative, and the African Independence Party represented the radical left.

${ }^{3}$ The concept of coloniality was introduced by the Peruvian sociologist Anibal Quijano and elaborated by the Argentinian semiotician Walter D. Mignolo and others, including Nelson Maldonado-Torres.

${ }^{4}$ Here, I use the term 'polyphonic' to signal a text in which multiple voices can be discerned but in which single utterances can be understood as dialogic (see Bakhtin 1981).
} 